\title{
一論 文一
}

（日本化学会誌，1981，（4），p. 530～535）

(C) 1981 The Chemical Society of Japan

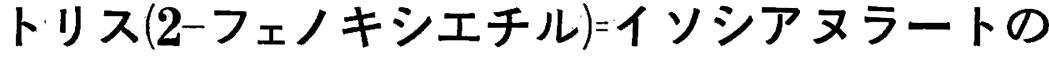 熱的挙動と質量スペクトル ${ }^{122}$}

\author{
（1980 年 10 月 9 日 受理）
}

島崎長一郎*・丹 羽 政 敏・長谷川 寛・尾 近 雅 敏

トリス(2-ヒドロキシェチル)ニ゙イシアヌラート (THEIC) とフェノールとの反応によってトリアジ

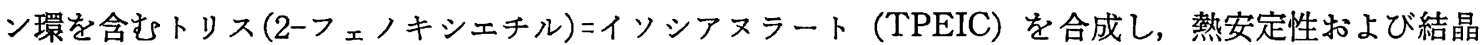
多形について検討した。TPEIC の熱分解は熱分析の手段により検討し，熱的にかなり安定な物質であ り，融点まで加熱したのち，冷却条件により，結晶二形を示すことがわかった。この結晶二形（A， B 形）の熱的挙動はほとんど差がなかった。TPEIC は再結晶溶媒により析出結晶が異なり，結晶二形の 単離ができ,これら二形の相互転換について検討した。この結晶二形の固体状態に括ける赤外吸収スペ クトル，X線回折図拉よ゙ DTA 曲線はいちじるしく異なる。電子衝撃による分解では TPEIC の分 子イオンピークは明膫に検出され，その他フラグメントイオンのピークから TPEIC の開裂様式を検討 した。その結果, 開裂は三つの側鎖が順序よく切断されたのち、トリアジン環の開裂が生じることがわ かった。

\section{1 緒言}

トリス(2-ヒドロキシェチル)=イソシアヌラート（以下 THEIC と略記する) は耐熱性の良好な 3 価のアルコールであり，前報2 のトリス(2,3-エポキシプロピル)=イソシフヌラート（以下 TEPIC と略記する）と同様にフェノール類と反応する。TEPIC はフェ ノール類とトリアジン環の開裂が生じて反応する ${ }^{8)}$ 。一方, THEIC は TEPIC の場合とフェノール類との反応条件は異なるが, トリ アシン環のオキサゾリジンン環への開裂なしに反応する。

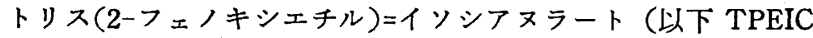
と略記する）(佐藤ら行とってはじめて合成された。著者らは TPEIC は反応時間により收率がかなり異なることを見いだした。 また，再結晶溶媒により結晶形が異なり，結晶多形の現象を示し た。このよらな報告は現在のところ，まだみられない。以上のこ とから，上述の現象を含めた固体化学的な研究を行ならために, 熱分析による熱的挙動および熱電子衝撃による開裂機構について 検討した。

\section{2 実験}

2.1 試 料

TPEIC 合成の原料である THEIC は日産化学株式会社製試薬

富士大学工学部工業化学科, 933 高岡市中川園町

1）この報文を“トリアシシン系化合物の分解，生成に関する研 究 (第 8 報)”とする.

2）前報(第 7 報), 島崎長一郎，飯野雄三，斎藤正人，日化， 1979, 1734.

3) Henkel \& Cie. G. m. b. H., Fr. P., 1, 487, 641(1967).

4) 佐藤義文, 神戸正樹, 徳地秀明, 高橋秋水, 科学と工業, $43,441(1969)$. をメタノールから再結晶して使用した。フェノール、p-トルェン スルホン酸（以下 PTS と略記する）扣よびキシレンはいずれも 市販品（試薬一級）をそのまま使用した。

\section{2 機器分析}

熱分析は三田村製の常压，減圧両用 DTA 装置之理学電機製の サーモフレッグス差動 TG-DTA 装置とを併用した。いずれも中 性体として $\alpha$-アルミナ粉を使用し，昇温速度を $5 \mathrm{~K} / \mathrm{min}$ で行な った。また，赤外吸収スペクトルは日本分光製 IRA-I 型を使用 し，臭化カリウム錠剤法で測定した。粉末 $\mathrm{X}$ 線回折は理学電機製 $\mathrm{X}$ 線回折計 $\mathrm{D}-3 \mathrm{~F}$ 型を使用し, $\mathrm{Fe}$ 対陰極, $\mathrm{Mn}$ フィルターを使 用し，印加電压 $35 \mathrm{kV}$ ，電流 $5 \mathrm{mA，スキャンスピード} 1 \%$ min で測定した。質量スペクトルは日本電子製質量分析器 JEOL, JMS-D 300 を使用し，PFK により補正したのち，直接導入法に より，イオン化電压 $75 \mathrm{eV}$ で測定した。また，高分解能質量分 析 JMS-D 300 も併用して, 開裂様式を検討した。

2.3 化学分析

酸価 $(A . V$.$) は Fritz の方法5)により測定し，(1)式により$ 算出した。

$$
A . V .=\frac{\left(\mathrm{NaOCH}_{3} \text { の規定度 }\right)(\mathrm{KOH} \text { の分子量 })}{\left(\mathrm{NaOCH}_{3} \text { の滴定量 }\right)}
$$

THEIC 残基 (T.R.) は宮内らの)がメラミン残基を求める方法 に準じて行なった。計算式として(2)式を用いた。(2)式中 $N$ は 試料の窒素含有率 $(\%)$ である。

$$
T . R .=\frac{14.0 \times 3}{N} \times 100
$$

5) S. Fritz, T. Keen, Anal. Chem., 25, 179(1953).

6）宮内徳之，竹下寿雄，工化，71，438(1968). 


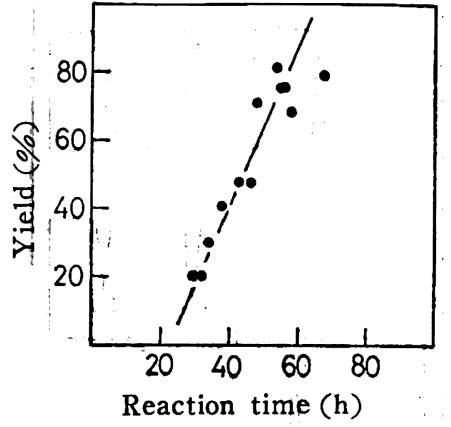

Fig. 1 Effect of reaction time on the yield of tris(2-phenoxyethyl)isocyanurate (TPEIC)

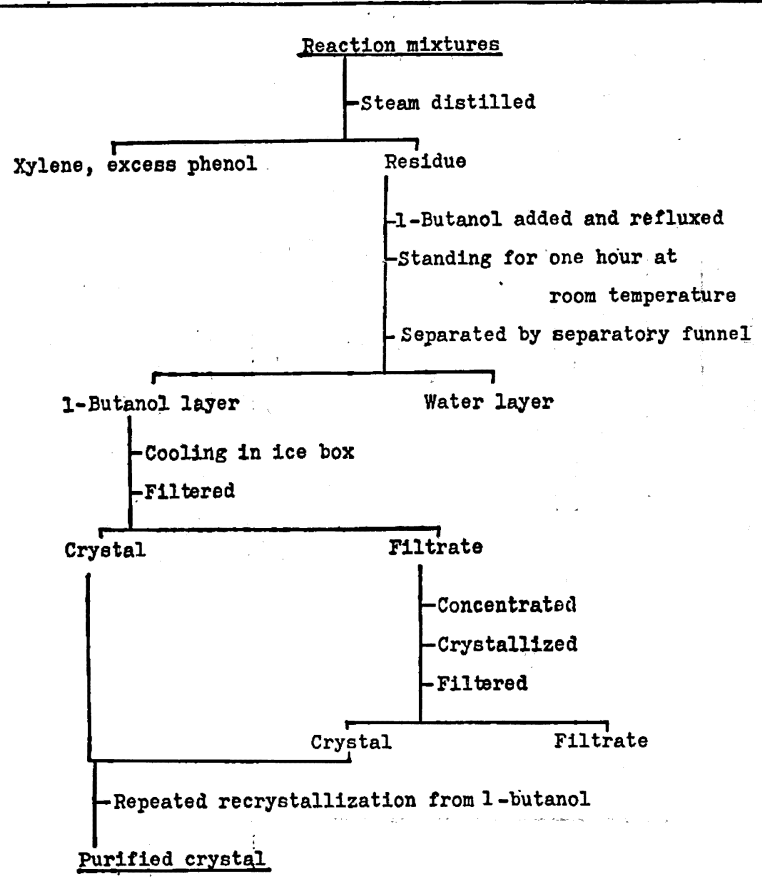

Fig. 2 Scheme of typical isolation procedure for tris $(2-$ phenoxyethyl)isocyanurates from the reaction mixtures

\section{4 薄層クロマトタラフィー}

吸着剂は Merck 社製のシリカゲル粉末を使用し, 薄層クロマ トグラフィーの展開溶媒はクロロホルムを用いた。

\section{5 熱 分 解}

磁製るつぼに一定量の試料を入れ，電気炉中で加熱した。测定 温度は $373 ， 573 ， 623 \mathrm{~K} て ゙$ 行なった。各時間ごとに試料を分取し たのち，大気中で室温まで泠却した生成物についてその性状を調 べた。加熱は大気中で行なった。

\subsection{TPEIC の合成}

佐藤ら4)の方法を参照にして合成した。還流冷却器をつけた丸 底フラスコ $(100 \mathrm{ml})$ に THEIC を $2.6 \mathrm{~g}(0.010 \mathrm{~mol})$, フェノ ール 37. $6 \mathrm{~g}(0.400 \mathrm{~mol})$, キシレン $15 \mathrm{ml}(0.142 \mathrm{~mol})$, PTS 0.5 $\mathrm{g}(0.003 \mathrm{~mol})$ を入れたのち, 縮合により脱離した水がキシレン と共沸しなくなるまで油浴中（453土2K）で還流した。還流時間 により収率が異なり，図１に示すような関係が得られた。収率を $70 \%$ 以上にするには反応時間が 50 時間必要である。反応終了
Table 1 Physical properties of tris(2-phenoxyethyl) isocyanurate

Elemental analysis

$\begin{array}{ccc}\mathrm{C}(\%) & \mathrm{H}(\%) & \mathrm{N}(\%) \\ 66.31 & 5.53 & 8.71 \\ (66.24)^{a)} & (5.57) & (8.59)\end{array}$

Melting point ${ }^{b}$

103. $0 \sim 104.0,115.0 \sim 116.0^{\circ} \mathrm{C}$

$\left(107.0 \sim 108.5^{\circ} \mathrm{C}\right)^{b)}$

$R_{\mathbf{f}}$ value $^{c)}$

0.59

Mass spectrum $m / e\left(\mathrm{M}^{+}\right)$

489

THEIC residue ${ }^{d)}$

482

Acid value

0.44

Benzene ring content/Triazine ring content $t^{e)}$ 2.92

a) Calculated values.

b) Literature values").

c) For thin layer chromatography.

d) Obtained from following equation: THEIC residue $(T . R)=.(14.0 \times 3) /$

(Nitrogen content, $\%) \times 100$.

e) Obtained from equation :

Ratio of benzene ring to triazine ring $=\frac{[T \cdot R \cdot-(M \cdot W \cdot \text { of THEIC }-17 \times 3)]}{[M . W . \text { of phenol-1.0] }}$

後, 反応混合物は水蒸気蒸留などを行なって処理した。詳細な処 理法は図 2 に示した。図 2 で得た精製結晶の物性值は表 1 のよう である。

表 1 から, TPEIC は二つの融解温度をもち, 低温形と高温形 の二形が存在するごとを示唆している。また，質畺スペクトルの 分子イオンピーク, 酸価, THEIC 残基およびィソシアヌル酸環 1 個あたりの芳香環の含量の計算值から，三置換体であることが 明瞭に認められた。酸洒の值から THEIC 残基に含まれるフェノ ール性ヒドロキシル基数を計算すると 0.004 となり，ほとんど完 全にフェノールが反応していることがわかる。

\section{3 実験結果之考察}

\subsection{TPEIC の熱的挙動}

TPEIC を空気中で昇温速度 $5.0 \mathrm{~K} / \mathrm{min}$ で昇温させたときの TG，DTG，DTA を測定したところ，図3に示すとおりである。 TG, DTG 曲線はいずれも一段階で反応が終了していることを示 している。また, DTA 曲線も分解のピークは1本しか見あたら なく，一段階反応であることを示している。融解によるピークは 2本あり，TPEIC は結晶多形の物質であることを示唆する。熱 的挙動をさらに詳細に検討するために顕微鏡による加熱過程の变 化を観察した。顕微鏡観察の結果は図 4 のよらである。

図 4 は一連の加熱温度のうち，いちじるしく変化が認められた 温度での状態を示したものである。この結果から， $359 \mathrm{~K}$ 付近か ら融解し始め, $367 \mathrm{~K}$ の温度にいたって A形の高温形の結晶生長 が認められ， $377 \mathrm{~K}$ で針状結晶が鮮明に存在することがわかる。 $379 \mathrm{~K}$ の温度に到達して融解が完全に終了する。この現象からも TPEIC は多形現象を示す結晶であると推定される。 

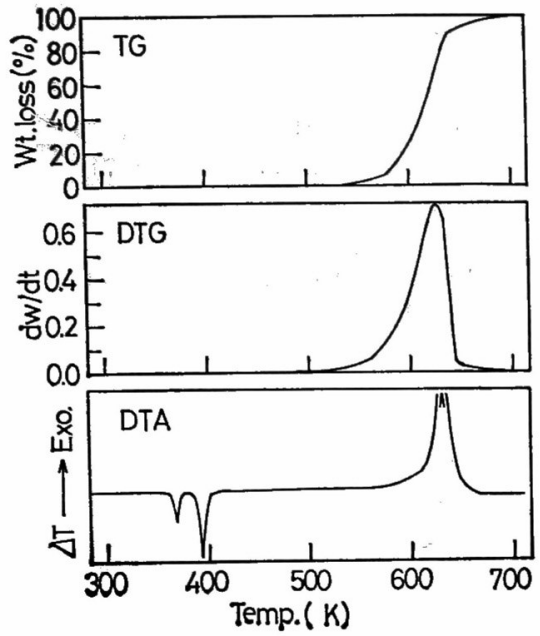

Fig. 3 TG, DTG, and DTA curves for TPEIC

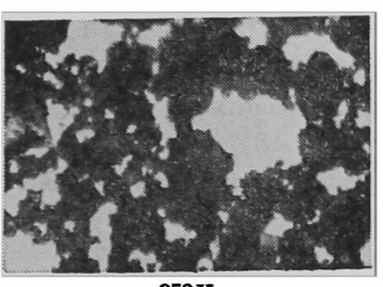

$353 \mathrm{~K}$

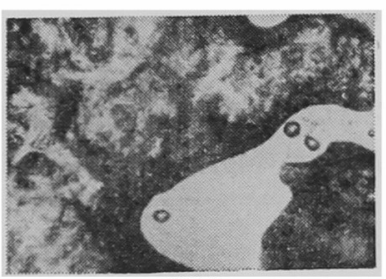

376K

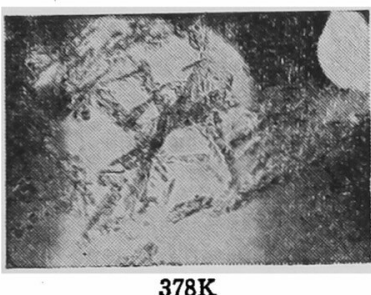

$378 \mathrm{~K}$

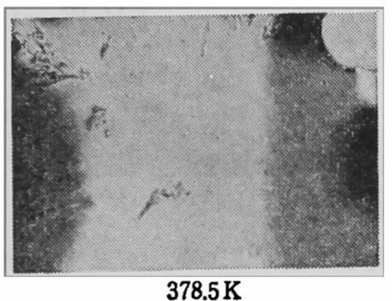

$378.5 \mathrm{~K}$
Fig. 4 Microphotographs of TPEIC at various temperatures

\subsection{TPEIC の結晶多形}

前節の熱的挙動の結果, 結晶二形を示す物質であると示唆され た。これをさらに別の観点から考察するために, TPEIC の冷却 条件による影響を DTA で検討した。その結果を図 5 に示した。 図 5 から，TPEIC を加熱すると $368 \mathrm{~K}$ で低温形 (B型) の融解 と高温形 (A型) に移行し，さらに加熱すると $394 \mathrm{~K}$ で高温形の 融解のピークを示す。融解液を徐冷すると $331 \mathrm{~K}$ で凝固をともな ら結晶化熱による発熱ピークが認められる。これは室温安定形の 結晶であることが，再加熱の DTA 曲線の測定結果から明瞭であ る。他方, 融解液を液体窒素で急冷すると透明な物質が得られ,

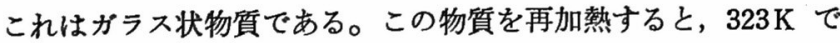
ガラス転移温度 $T_{\mathrm{g}}$ を示し，この温度を過きて加熱をつづけると $338 \mathrm{~K}$ で低温結晶化を起こすが，これは準安定形の高温形である ことがその熱的挙動から明らかである。

結晶多形を化学的な観点から確認するために溶媒効果の検討を 行なった。TPEIC の再結晶を極性の異なる 6 種類の溶煤を使用 して行なった。その物性值を表 2 に示す。表 2 の結果から, 再結 晶した TPEIC はいす゚れる結晶溶媒を含まない純粋な TEPIC 結 晶と見なすことができる。ベンゼンおよびアセトンからはA形の

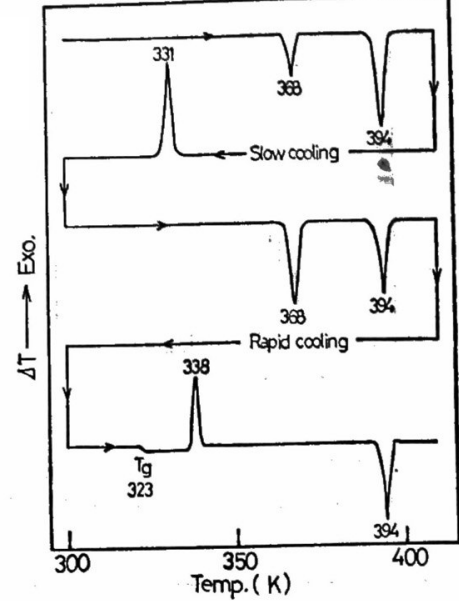

Fig. 5 DTA curves for TPEIC under different cooling conditions

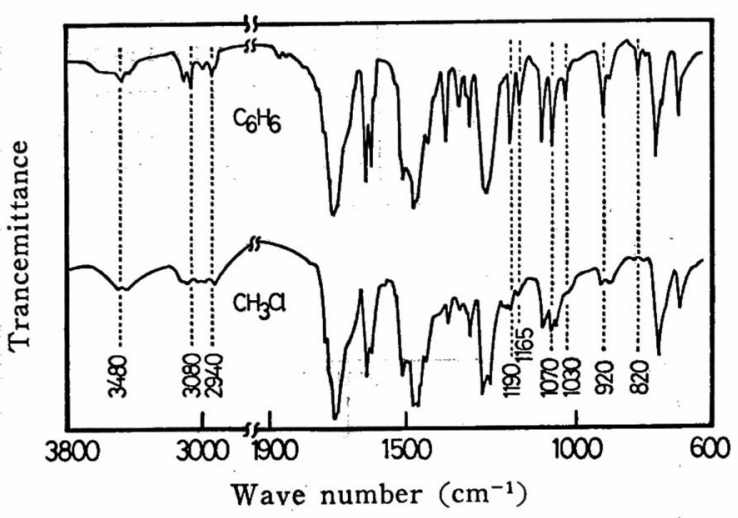

Fig. 6 IR spectra of TPEIC in $\mathrm{KBr}$ disks

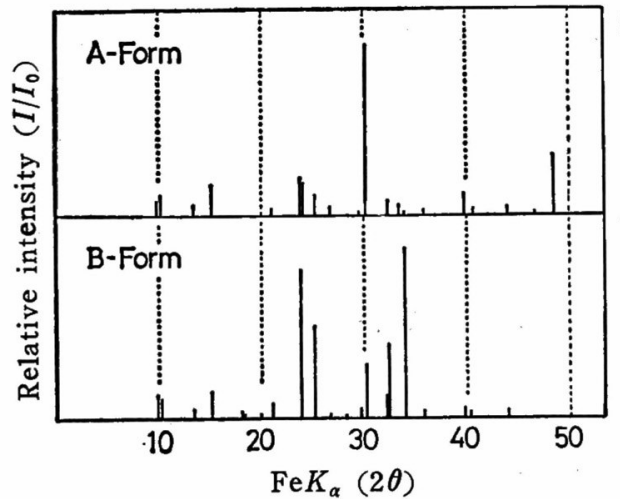

Fig. 7 X-ray diffraction profiles of TPEIC

結晶形が得られ，その他の溶媒から得られた結晶は B 形であっ た。

A，B両形の結晶の赤外吸収スペクトルを図 6 に示す。図 6 か ら, 二形間のスペクトル強度，位置の相違はトリアジン環側鎖の アルキル基の吸収に基つく $2900 \sim 3100 \mathrm{~cm}^{-1}$ の領域と指紋領域の $800 \sim 1200 \mathrm{~cm}^{-1}$ の領域で特異的である。THEIC のトリアジ環 に基づく吸収 $759 \mathrm{~cm}^{-1}$, フェノールに起因する芳香族 $\mathrm{C}-0$ 単結 合の吸収 $1242 \mathrm{~cm}^{-1}$, 一置換ベンゼンの吸収 $695 \mathrm{~cm}^{-1}$ は A, B 両 形では同一な位置, 強度で現われている。 
Table 2 Physical properties of recrystallized tris(2-phenoxyethyl) isocyanurate under various conditions

Elemental analysis (\%)

\begin{tabular}{|c|c|c|c|c|c|c|c|c|c|}
\hline \multirow{3}{*}{ Solvents } & \multirow{3}{*}{$\begin{array}{l}\text { Dipole moment } \\
\text { (Debye) }\end{array}$} & \multirow{2}{*}{\multicolumn{2}{|c|}{ C }} & \multirow{2}{*}{\multicolumn{2}{|c|}{$\underbrace{\mathrm{H}}$}} & \multirow{2}{*}{\multicolumn{2}{|c|}{$\mathrm{N}$}} & \multirow{3}{*}{$\mathrm{mp}\left({ }^{\circ} \mathrm{C}\right)$} & \multirow{3}{*}{$\begin{array}{c}\text { Crystal } \\
\text { form }\end{array}$} \\
\hline & & & & & & & & & \\
\hline & & Obs. & Calc. & Obs. & Calc. & Obs. & Calc. & & \\
\hline Benzene & 0.00 & 66.33 & \multirow{6}{*}{66.24} & 5.71 & \multirow{6}{*}{ 5. 56} & 8.86 & \multirow{6}{*}{8.58} & 105. $0 \sim 106.5$ & A \\
\hline Carbon tetrachloride & 0.00 & 66.02 & & 5.57 & & 8.60 & & $102.5 \sim 104.5$ & B \\
\hline Toluene & 0.37 & 66.20 & & 5.56 & & 8.54 & & $105.0 \sim 106.5$ & B \\
\hline Chloroform & 1.06 & 66.12 & & 5.57 & & 8. 54 & & $102.5 \sim 105.0$ & B \\
\hline Ethanol & 1. 67 & 66.24 & & 5.55 & & 8. 57 & & 103. $0 \sim 106.5$ & B \\
\hline Acetone & 2. 85 & 66.48 & & 5.79 & & 8. 24 & & $\left\{\begin{array}{l}104.5 \sim 106.0 \\
112.5 \sim 114.0\end{array}\right.$ & $\boldsymbol{A}$ \\
\hline
\end{tabular}

Table 3 Mass spectral data of tris(2-phenoxyethyl) isocyanurate

\begin{tabular}{|c|c|c|c|c|c|}
\hline$m / e^{a)}$ & Relative intensity ${ }^{b)}$ & $\operatorname{Sigma}^{c)}(\%)$ & Observed molecular weight & U.S. ${ }^{e)}$ & Probable ion composition \\
\hline 70.0 & 15.07 & 5. 27 & $70.0205(70.0165)^{d)}$ & 3.0 & $\mathrm{C}_{2} \mathrm{H}_{2} \mathrm{~N}_{2} \mathrm{O}$ \\
\hline 113. 0 & 26. 07 & 9.12 & 113. $0222(113.0222)$ & 4.0 & $\mathrm{C}_{3} \mathrm{H}_{3} \mathrm{~N}_{3} \mathrm{O}_{2}$ \\
\hline 120.0 & 5.96 & 2. 08 & $120.0484(120.0573)$ & 5.0 & $\mathrm{C}_{8} \mathrm{H}_{8} \mathrm{O}$ \\
\hline 121.0 & 15. 38 & 5. 38 & $121.0651(121.0651)$ & 4.5 & $\mathrm{C}_{8} \mathrm{H}_{9} \mathrm{O}$ \\
\hline 156. 0 & 2.63 & 0.92 & 156. $0418(156.0405)$ & 4.5 & $\mathrm{C}_{5} \mathrm{H}_{6} \mathrm{~N}_{3} \mathrm{O}_{8}$ \\
\hline 182.0 & 42.08 & 14. 71 & $182.0531(182.0561)$ & 5.5 & $\mathrm{C}_{7} \mathrm{H}_{8} \mathrm{~N}_{3} \mathrm{O}_{3}$ \\
\hline 183. 0 & 3. 16 & 1. 10 & & & \\
\hline 198. 0 & 2. 68 & 0.94 & & & \\
\hline 199. 0 & 1. 79 & 0.62 & & & \\
\hline 249.0 & 1. 27 & 0.44 & & & \\
\hline 276. 0 & 15.71 & 5. 49 & 276. $0968(276.0978)$ & 8.5 & $\mathrm{C}_{13} \mathrm{H}_{14} \mathrm{~N}_{3} \mathrm{O}_{4}$ \\
\hline 277.0 & 2.38 & 0.83 & $277.1003(277.1056)$ & 8. 0 & $\mathrm{C}_{13} \mathrm{H}_{15} \mathrm{~N}_{3} \mathrm{O}_{4}$ \\
\hline 369.0 & 1. 60 & 0.56 & & & \\
\hline 396.0 & 100.00 & 34.97 . & 396. 1492 (396. 1551) & 12.5 & $\mathrm{C}_{21} \mathrm{H}_{22} \mathrm{~N}_{3} \mathrm{O}_{5}$ \\
\hline 397.0 & 25. 80 & 9.02 & $397.1662(397.1629)$ & 12. 0 & $\mathrm{C}_{21} \mathrm{H}_{23} \mathrm{~N}_{3} \mathrm{O}_{5}$ \\
\hline 489.0 & 5.33 & 1.86 & 489. 1859 (489. 1890) & 16.0 & $\mathrm{C}_{27} \mathrm{H}_{27} \mathrm{~N}_{3} \mathrm{O}_{6}$ \\
\hline$\overline{490.0}$ & 2. 22 & 0.77 & 490.1954 (490.1968) & 15.5 & $\mathrm{C}_{27} \mathrm{H}_{28} \mathrm{~N}_{3} \mathrm{O}_{6}$ \\
\hline a) & \multirow{5}{*}{\multicolumn{5}{|c|}{$\begin{array}{l}\text { Molecular ion is underlined. } \\
\text { Relative intensity referred to base peak of spectrum as } 100 \text {. } \\
\text { Peak heights expressed in per cent of total ionization }(\mathrm{m} / e 50 \text { to } \mathrm{m} / \mathrm{e} 500) \text {. } \\
\text { Calculated values. }\end{array}$}} \\
\hline b) & & & & & \\
\hline c) & & & & & \\
\hline$d)$ & & & & & \\
\hline$e)$ & & & & & \\
\hline
\end{tabular}

赤外吸収スペクトルの相違は結晶中での分子間相互作用に依存 して打り，1030,1070 $\mathrm{cm}^{-1}$ 付近の芳香族ェーテルの吸収は $\mathrm{A}, \mathrm{B}$ 間で異なり, TPEIC の結晶構造の相違が -O- 基の配向に起因し ているものと推察される。結晶構造の相違を確かめるためにX線 回折を行なった。その結果は図 7 で示したよらに A，B両形でい ちじるしく異なっていることがわかる。このことからも TPEIC は結晶多形の物質であることが確認される。

\section{3 質量スペクトル}

前節まで TPEIC の熱的挙動, 結晶多形について記述してきた が, 熱的挙動は化学反応の立場から電子衝撃による開裂様式と類 似しているといわれていることから，電子衝撃による質量スペク トルを検討した。TPEIC の A， B両形の質量スペクトルには相 違が認められなかったので, 両形を含む試料についての結果を図 8 に示した。図 8 中の各ピークについて高分解能質量スペクトル を測定した。その結果は表 3 に示すとおりである。

表 3 の結果から，高分解能質量スペクトルで得られた実测の分 子量は計算值とよく一致していることがわかる。この表 3 に基づ いて，熱電子衝撃による開裂様式を推定した。その結果は図式 1 のとおりである。図式は TPEIC の構成成分であるトリアジン環 が開裂するまでの図式が表示してある。この図式は著者らが以前

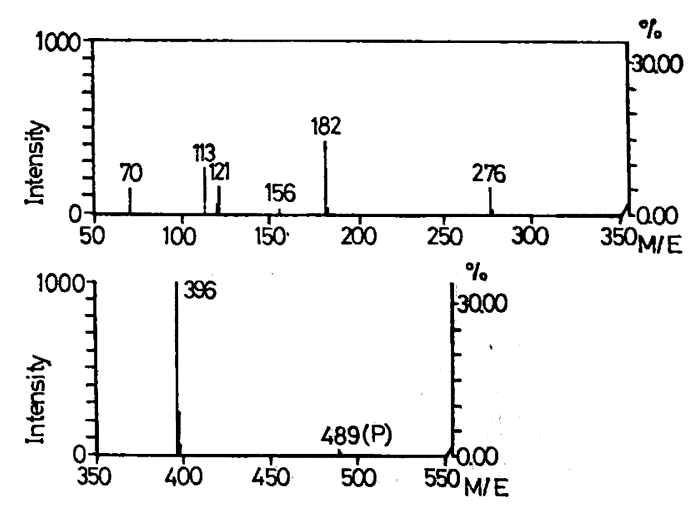

Fig. 8 Mass spectra (from $m / e 50$ to 500 ) of TPEIC

に報告したイソシアスル酸トリス(ヒドロキシアルキル)エステル の質量スペクトルの論文7中での開裂機構とは異なる。既報では 開裂機構の様式として 3 種類举げ, そのららの 1 種類としてトリ アジン環がただちに開裂していく経路が存在することを示した。 これは衝撃電压が $20 \mathrm{eV}$ の低電压に拉いても分子イオンピーク の $m / e$ の $1 / 3$ の值を示すフラグメントピークが生じることから

7）島崎長一郎, 名嘉山 隆, 飯野雄三, 日化, 1979, 375. 


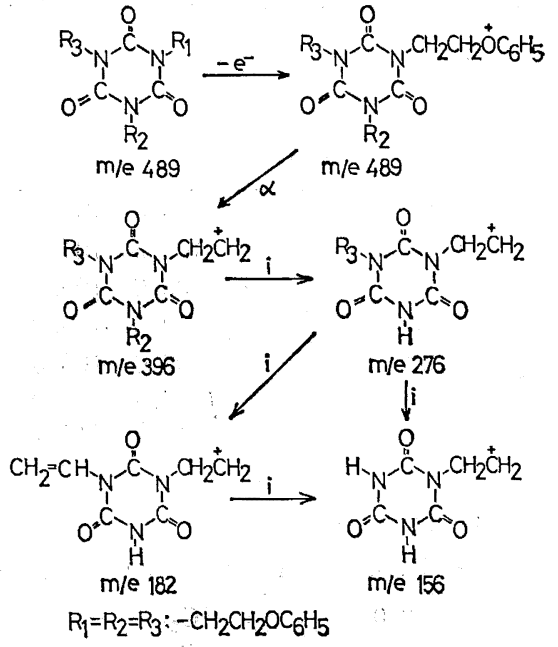

Scheme 1

確認した。

本報では衝撃電圧を $18 \mathrm{eV}$ の低電圧に降下しても, 分子イオン ピークの $1 / 3$ の m/e のフラグメントピークは生じないことから, トリアジン環の開裂がただちに生じる過程は考えられない。トリ アジン環の三つの側鎖 $\left(-\mathrm{CH}_{2} \mathrm{CH}_{2} \mathrm{OC}_{6} \mathrm{H}_{5}\right)$ が順序よく切断される 過程を通ったのち，環開裂が生じる。側鎖の開裂は第 1 段階では $-\mathrm{OC}_{6} \mathrm{H}_{5}$ ，第 2 段階では $-\mathrm{CH}_{2}=\mathrm{CHOC}_{6} \mathrm{H}_{5}$, 第 3 段階では $-\mathrm{OC}_{6} \mathrm{H}_{5}$ (または $-\mathrm{CH}_{2}=\mathrm{CHOC}_{6} \mathrm{H}_{5}$ ) が順番に切断されていく傾向が認めら れる。前節の熱分析の手段ではこれらの過程が連続して生じるの で 1 段階ですべての分解が起こるように現われ，区別することが できないと考えられる。

\section{4 熱分解過程の動力学}

TPEIC の熱分解を 2.5 の方法により等温過程で行なった。そ の結果を図 9 に示す。図 9 から $473 \mathrm{~K}$ では 5 時間経過後でもほと んど重量損失は認められなく, $573 \mathrm{~K}$ では 5 時間経過後で $30 \%$ の 重量損失がある。また $623 \mathrm{~K}$ にいたると，1 時間後にすでに $30 \%$ の重量損失が認められ， 5 時間経過すると $80 \%$ 重量損失が認め られる。これら等温過程での赤外吸収スペクトルを測定すると， 試料自身はかなり着色しているが，TPEIC の側鎖に依存する 2940, $3080 \mathrm{~cm}^{-1}$ のアルキル 基の吸収が加熱温度が上昇するにつ れ，また加熱時間が増加するにつれて変化するだけでイソシアヌ ル酸環の $759 \mathrm{~cm}^{-1}$ の吸収が残っていることから，質量スペクト ルの結果と同様，側鎖の切断が起こったのち，トリアジン環の開 裂が生じることを示唆している。

熱分析による TPEIC の熱的挙動では熱分解が連続して一段階 で生じていることを前に述べた。これは，この熱分解反応が見か け上ただ一つの活性化ェネルギーで支配されている。そこで熱分 析の理論8) 11)により活性化エネルギーを算出した。図 $10(\mathrm{a})$ は 昇温速度 $0.625,1.25,2.50,5.0 \mathrm{~K} / \mathrm{min}$ で測定した TG 曲線で ある。この TG曲線をもとにして小沢 ${ }^{8) 9}$ と Freeman, Carrol1 ${ }^{10}$ の方法によって活性化エネルギーを求めた。図 $10(\mathrm{~b})$ は小沢の

8) T. Ozawa, Bull. Chem. Soc. Jpn., 38, 1881(1965).

9) T. Ozawa, J. Therm. Anal., 2, 301(1970).

10) E. S. Freeman, B. Carroll, J. Phys. Chem., 62, 394 (1958).

11) H.E. Kissinger, Anal. Chem., 29, 1702(1957).

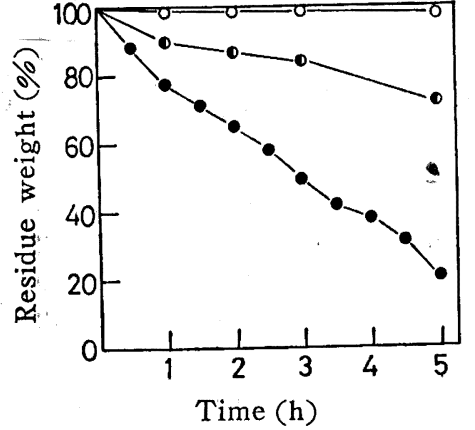

Fig. 9 TG curves of isothermal process at various temperatures

Temp. (K) ;

$$
\text { : }: 473 \text {, D:573, }: 623
$$

(a)

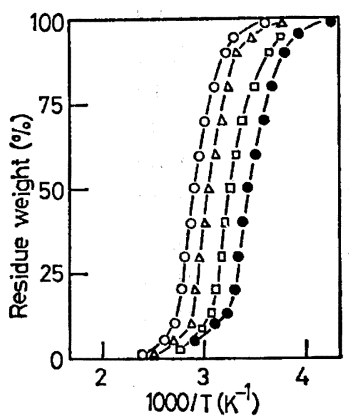

(b)

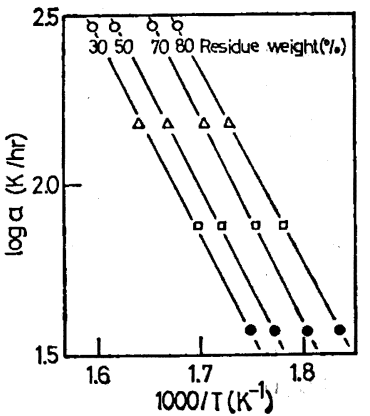

Fig. 10(a) TG curves of TPEIC plotted against reciprocal of absolute temperature

(b) Plots of logarithms of heating rate versus the reciprocal of absolute temperature for given conversions of decomposition of TPEIC

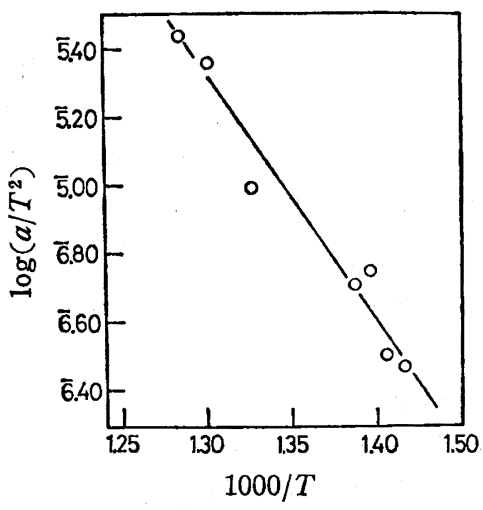

Fig. 11 Kissinger's plots

プロットで，残存重量が $30 ， 50 ， 70 ， 80$ 重量百分率のところで， 各昇温速度の対数と絶詨温度の関係を表わしたものである。この 傾さから活性化ェネルギーを求めると， $106.7 \mathrm{KJ} / \mathrm{mol}$ である。 また，各昇温速度の TG 曲線より，Freeman, Carrol1 ${ }^{10)}$ の式か ら昇温速度を $0 \mathrm{~K} / \mathrm{min}$ に外挿した值での活性化エネルギーを算 出すると $136.4 \mathrm{KJ} / \mathrm{mol}$ であった。

つぎに, DTA 曲線のピーク温度が界温速度に依存し，な招か つ最終的に反応次数に関係がないという Kissinger の式11を使 
用して，分解の活性化エネルギーを算出した。Kissinger プロッ トをして，そのプロットから最小二乗法で直線の式を求めると図 11 のよである。この直線の傾きから活性化エネルギーを計算す ると $139.7 \mathrm{KJ} / \mathrm{mol}$ の值が得られた。この值は Freeman, Carroll の方法で得た值とほほ等しいことがわかる。

最後に本研究を行ならにあたり, 試料を提供された日産化学工
業株式会社, $X$ 線回折, 熱重量測定, 質量スペクトル测定に便宜 をはかっていたたいた本学工学部の池田正夫教授, 宇佐美四郎教 授, 長谷川 淳助教授, 島崎利治講師, 栗山佳則氏, 教育学部の 野村 其教授，竹内茂弥助教授，ならびに元素分析の測定に協力 いたたいた富山医科大学の元素分析室の諸氏に深謝致します。 （1980 年 9 月，日本化学会第 42 秋季年会発表）

\title{
Thermal Behavior and Mass Spectrum of Tris(2-phenoxyethyl) Isocyanurate ${ }^{\dagger}$
}

\author{
Choichiro ShImasaki*, Masatoshi Niwa, Hiroshi Hașegawa \\ and Masatoshi OKon \\ Faculty of Engineering, Toyama University ; Nakagawasonomachi, \\ Takaoka-shi 933 Japan
}

Tris(2-phenoxyethyl) isocyanurate (TPEIC) was prepared by the reaction of tris (2-hydroxyethyl) isocyanurate with phenol and was found by the thermal analysis techniques to be thermally stable and to have dimorphic crystals depending on the cooling conditions of DTA. No difference in the pyrolytic behavior was observed in these dimorphic crystals. These dimorphic crystals showed marked differences in DTA curves (Fig. 5), IR spectra (Fig. 6), and X-ray diffraction patterns (Fig.7), however. In the decomposition by electron impact, the molecular ion peak was detected clealy. The fragmentation of a triazine ring was considered to take place after successive cleavage of the three side chains of TPEIC.

$\dagger$ Studies on Decomposition and Formation of Triazine Series Compounds. VIII. 